\title{
First isolation and characterization of Chryseobacterium shigense from rainbow trout
}

\author{
Leydis Zamora', Ana I. Vela ${ }^{1,2}$, Mª Angel Palacios $^{3}$, Lucas Domínguez ${ }^{1}$ and José Francisco Fernández-Garayzábal ${ }^{1,2^{*}}$
}

\begin{abstract}
Background: There have been an increasing number of infections in fish associated with different species of Chryseobacterium, being considered potentially emerging pathogens. Nevertheless the knowledge of the diversity of species associated with fish disease is partial due to the problems for a correct identification at the species level based exclusively on phenotypic laboratory methods.

Results: Chryseobacterium shigense was isolated from the liver, kidney and gills of diseased rainbow trout in different disease episodes that occurred in a fish farm between May 2008 and June 2009. Identity of the isolates was confirmed by $16 \mathrm{~S}$ rRNA gene sequencing and phenotypic characterization. Isolates represented a single strain as determined by random amplified polymorphic DNA analysis.
\end{abstract}

Conclusions: This is the first description of the recovery of $C$. shigense from clinical specimens in trout, a very different habitat to fresh lactic acid beverage where it was initially isolated.

\section{Background}

Members the genus Chryseobacterium are widely distributed microorganisms that can be recovered from a wide variety of environments, such as fresh water, sewage and wastewater, soil or food sources, such as milk, poultry and meat and dairy products [1]. Some species of Chryseobacterium have been involved in human infections, acting as sporadic but severe opportunistic nosocomial pathogens $[2,3]$. In veterinary medicine, chryseobacteria are not relevant pathogens for domestic animals, but they are widely distributed in aquatic environments and fish farms [1,4]. Until recently members of the genus Chryseobacterium were not commonly associated with fish infections. However, there has been an increase in the frequency of clinical cases in which Chryseobacterium sp. strains have been isolated from different fish species. Thus, Chryseobacterium balustinum, Chryseobacterium scophtalmum and Chryseobacterium joostei have been isolated from diseased fish [4-6]. More recently, Chryseobacterium piscicola has been reported

\footnotetext{
*Correspondence: garayzab@vet.ucm.es

${ }^{1}$ Centro de Vigilancia Sanitaria Veterinaria (VISAVET). Universidad

Complutense, 28040 Madrid, Spain

${ }^{2}$ Departamento de Sanidad Animal. Facultad de Veterinaria, Universidad

Complutense, 28040 Madrid, Spain

Full list of author information is available at the end of the article
}

to produce mortalities in farmed Atlantic salmon (Salmo salar) and rainbow trout (Oncorhynchus mykiss) in Chile and Finland [7-9], Chryseobacterium arothri was isolated from the kidneys of the pufferfish Arothron hispidus in Hawaii [10] and Chryseobacterium chaponense from diseased farmed Atlantic salmon in Chile [11]. In fact, some Chryseobacterium species are considered potentially emerging pathogens in fish [4]. However, many chryseobacteria isolated from diseased fish are usually identified only at the genus level due to the difficulty of their correct identification by phenotypically based laboratory methods alone $[4,5]$, which limits the knowledge of the diversity of species associated with fish disease.

\section{Methods}

\section{Bacterial strains and culture conditions}

The bacterial isolates were recovered from liver (635-08, 628-2-08; 692-08), kidney (664-09) and gills (706B-08, 972B-08, 1107B-09) of rainbow trout (Oncorhynchus mykiss) fry during five outbreaks (May, June and September of 2008 and June 2009) occurred in a fish farm located in the central region of Spain. The fish farm had a flow-through system with intake of water from an adjacent river. The water temperature is quite constant during the whole year $\left(15{ }^{\circ} \mathrm{C} \pm 1\right)$. Stocking densities 
vary along the growth period from 3 to $20 \mathrm{~kg} / \mathrm{m}^{3}$, with a water exchange rate of $15-20 \mathrm{~min}$. Feed consist in a commercial brand of extruded micropelets. Average feeding rate is about $3 \%$ of biomass, delivered in four times by hand. Based on clinical symptoms and epidemiological background (Flavobacterium psychrophilum had previously been isolated from the farm) rainbow trout fry syndrome (RTFS) was suspected. Trout were submitted alive to the Animal Health Surveillance Centre (VISAVET) of the Universidad Complutense of Madrid for a confirmatory microbiological diagnosis. Trout were euthanized and necropsied under aseptic conditions. Samples of liver, kidney and gills were incubated on Anacker and Ordal's agar for 7 days at $14{ }^{\circ} \mathrm{C}$. Nutrient agar was used for routinely growth of clinical isolates after their initial isolation. Stock cultures were preserved at $-80^{\circ} \mathrm{C}$ in a cryopreservative media composed of tryptone (2.5\%), unskimed milk (5\%) and glicerine (20\%).

\section{F. psychrophilum PCR assay}

The PCR assay specific for F. psychrophilum was performed as described by Wiklund et al. [12].

\section{$16 \mathrm{~S}$ rRNA gene sequencing}

The $16 \mathrm{~S}$ rRNA gene of the seven isolates was amplified and sequenced as described previously [13] and subjected to a comparative analysis. A nearly complete $16 \mathrm{~S}$ rRNA gene fragment $(>1,400 \mathrm{bp}$ ) was obtained bidirectionally using the universal primers pA (5'-AGAGTTT GATCCTGGCTCAG; positions 8-27, Escherichia coli numbering) and $\mathrm{pH}^{*}$ (5'-AAGGAGGTGATCCAGCC GCA; positions 1,541-1,522, E. coli numbering). The determined sequences were compared with the sequences of other Gram-negative species available in the GenBank database, by using the FASTA program (http://www.ebi. ac.uk/fasta33). Phylogenetic relationships were inferred using the neighbor-joining algorithm as described previously [14].

\section{Random amplified polymorphic DNA fingerprinting}

For all strains genomic DNA was prepared using method described by Marmur [15]. The primers used for RAPDPCR were P1 (5'-CTGCTGGGAC-3') and P2 (5'-CGC CCTGCCC-3') (Roche Diagnostics S.L.) described previously (3). PCR amplifications were performed using a commercial PCR master mix (kit QIAGEN Multiplex PCR) adding the DNA template $(5 \mu \mathrm{l}), 0.5 \mu \mathrm{M}$ of each primer and water up to a final volume of $25 \mu$ l. PCR amplifications were carried out in a Mastercycler gradient thermocycler (Eppendorf) with the following parameters: an initial denaturalization of $15 \mathrm{~min}$ at $95^{\circ} \mathrm{C}$ and 30 cycles of $1 \mathrm{~min}$ at $94{ }^{\circ} \mathrm{C}, 1 \mathrm{~min}$ at $36^{\circ} \mathrm{C}$, and $2 \mathrm{~min}$ at $72{ }^{\circ} \mathrm{C}$. PCR-amplified products $(20 \mu \mathrm{l})$ were separated at $60 \mathrm{~V}$ for $2 \mathrm{~h}$ in $1.5 \%$ agarose gel electrophoresis supplemented with 1X Syber safe ${ }^{\circledR}$ (Invitrogen, Eugene, OR). DNA banding patterns were analyzed using bioNumerics software (Applied Maths) to calculate Dice coefficients of correlation and to generate a dendrogram using the unweighted pair group method of arithmetic averages (UPGMA) clustering. To assess the repeatability of RAPD-PCR, isolates were submitted to three different amplifications assays for each primer, realized in different days and in similar conditions as described above.

\section{Phenotypic analysis}

Isolates were characterized using conventional phenotypic tests proposed by Bernardet et al. [16] i.e. production of catalase and oxidase, motility, hydrolysis of agar, casein, L-tyrosine, aesculin, DNA, urea, gelatin and starch; production of flexirubin-type pigments; growth on MacConkey (bioMérieux) and nutrient (Difco) agars and growth at $15,25,30,37$ and $42{ }^{\circ} \mathrm{C}$, with $3.0,4.5$ and $6.5 \%$ added $\mathrm{NaCl}$, and under anaerobic and microaerobic conditions, were determined as described previously [17]. The isolates were further biochemically characterized using the API 20NE and API ZYM systems (bioMérieux) according to the manufacturer's instructions, except that incubation temperature was $25{ }^{\circ} \mathrm{C}$. The type strain of C. shigense CCUG $61059^{\mathrm{T}}=$ DSM $17126^{\mathrm{T}}$ was used as a reference in all tests.

\section{Results}

All isolates gave shiny, round, yellow-pigmented colonies on Anacker and Ordal agar, a characteristic that lead to the presumptive diagnosis of infection by $F$. psychrophilum, but none of the isolates gave the expected amplicon product of $1,089 \mathrm{bp}$, specific of $F$. psychrophilum. Moreover, cells of trout isolates were straight short Gram negative rods after Gram staining. Comparative analysis of the $16 \mathrm{~S}$ rRNA gene sequences revealed that the isolates shared 99.8-100 \% sequence similarity between each other, thus demonstrating their high phylogenetic relatedness, 99.2-99.8 \%, with the type strain of $C$. shigense (GUM-Kaji $^{\mathrm{T}}$; Figure 1) and only 81.8-81.9 \% with F. psychrophilum NCIMB $1947^{\mathrm{T}}$ (GenBank accession $\mathrm{n}$ D12670). The $16 \mathrm{~S}$ rRNA gene sequences of the isolates included in this study have been deposited in GenBank under the accession numbers indicated in Figure 1.

Phenotypically all trout isolates were catalase and oxidase positive, non-motile, grew on nutrient agar with yellow and shiny colonies but not on MacConkey agar, produced flexirubin-type pigment, were able to grow at $5-30{ }^{\circ} \mathrm{C}$ but not at $37^{\circ} \mathrm{C}$, and hydrolysed starch, casein and gelatin. With the API 20NE system they exhibited homogeneous biochemical characteristics displaying the numerical profiles 3452205, while C. shigense CCUG $61059^{\mathrm{T}}$ gave the numerical profile 2456204 . With the APY ZYM strips, the trout isolates, as well as the type 


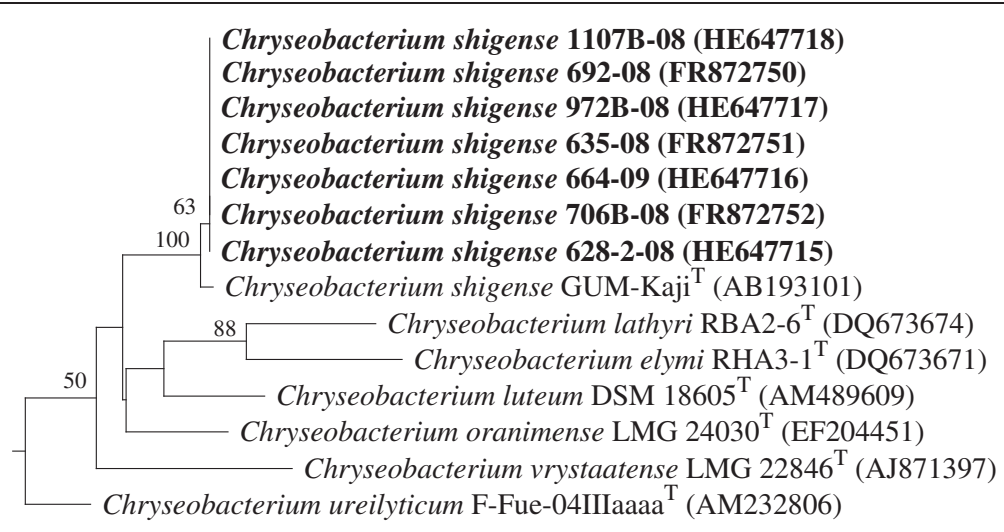

$1 \%$

Figure 1 Phylogenetic relationships of the clinically trout isolates and close related species in the genus Chryseobacterium inferred using the neighbor-joining method with 16 S rRNA gene sequences. Bootstrap values (expressed as a percentage of 1000 replications) $>50 \%$ are given at the branching points. Leeuwenhoekiella marinoflava ATCC 19326 ${ }^{\top}$ (M58770) was used as outgroup. Bar, $1 \%$ sequence divergence.

strain of C. shigense CCUG $61059^{\mathrm{T}}$, expressed activity for alkaline phosphatase, leucine arylamidase, trypsin, acid phosphatase and naphthol-AS-BI-phophohydrolase but not for esterase C4, lipase C14, cystine arylamidase, $\alpha$-chymotrypsin, $\alpha$-galactosidase, $\beta$-galactosidase, $\beta$ glucuronidase, $\alpha$-glucosidase, $N$-acetyl- $\beta$-glucosaminidase, $\alpha$-mannosidase and $\alpha$-fucosidase. Clinical isolates of $C$. shigense expressed activity for valine arilamidase and not for ester lipase $\mathrm{C} 8$ and $\beta$-glucusidase, while $C$. shigense CCUG $61059^{\mathrm{T}}$ gave opposite results for these tests.
After genetic characterization by random amplified polymorphic DNA, both oligonucleotides generated reproducible patterns, but an appropriate number on bands were produced with oligonucleotide P2 (Figure 2). The seven $C$. shigense trout isolates showed undistinguishable RAPD fingerprints with amplifications bands ranging from 600 to $2500 \mathrm{bp}$, indicating genetic homogeneity among them. On the other hand, the strain CCUG $61059^{\mathrm{T}}$ yielded a completely different fingerprint (Figure 2).

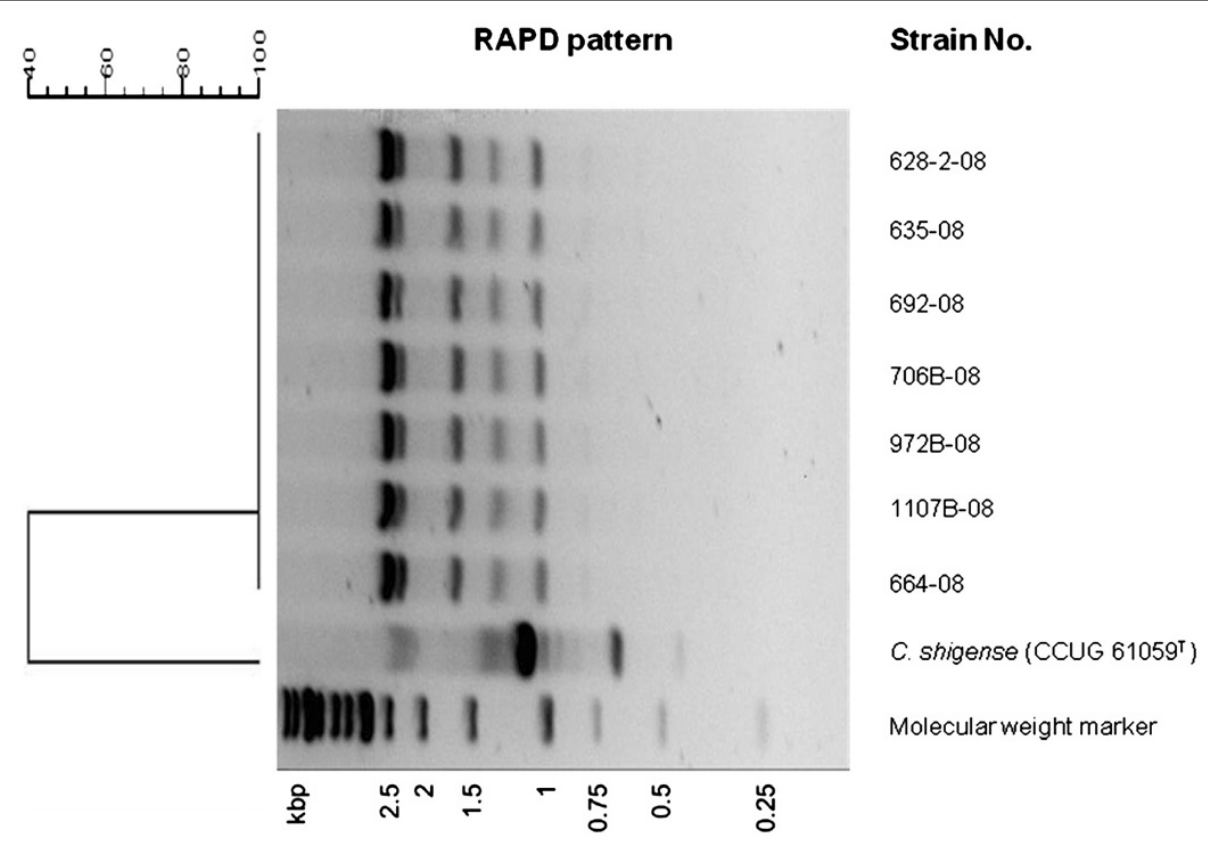

Figure 2 RAPD profiles obtained with primer P2 for the $C$. shigense strains and the dendrogram generated based on the Dice coefficient using the BioNumerics software (Applied Maths). 


\section{Discussion}

Diagnosis of bacterial fish diseases is not possible purely on the basis of the clinical signs and symptoms observed in diseased fish, because many of them can be caused by more than one etiological agent. Presumptive diagnosis is usually based on previous epidemiological data and a rough bacteriological analysis of cultured organisms from affected animals. In the present study, isolates were recovered from diseased trout suspected of F. psychrophilum infection because the fish farm had previous records of infections with this fish pathogen and the macroscopic characteristics of the colonies obtained on Anacker and Ordal agar were also compatible with that presumptive diagnosis. However, cell morphology of the trout isolates following Gram staining was different of the filamentous rods exhibited by F. psychrophilum [18], they were non-motile and none gave a positive reaction with a F. psychrophilum species-specific PCR assay [13]. This lack of amplification is consistent with the low similarity observed (81.8-81.9\%) between the $16 \mathrm{~S}$ rRNA gene sequences of trout isolates and F. psychrophilum NCIMB $1947^{\mathrm{T}}$. The trout isolates exhibited the highest $16 \mathrm{~S}$ rRNA sequences similarities with $C$. shigense GUM$\mathrm{Kaji}^{\mathrm{T}}$ (99.2-99.8\%), percentages higher than the $99 \%$ sequence similarity used as the criterion for species identification [19]. In addition, most of the phenotypic characteristics of the $C$. shigense trout isolates were consistent with the current description of this species based solely in the strain DSM $17126^{\mathrm{T}}$ [20], which support the identification based on $16 \mathrm{~S}$ rRNA gene sequencing. Despite the overall phenotypic similitude, some differences were found between the $C$. shigense trout isolates and the type strain C. shigense CCUG $61059^{\mathrm{T}}$. Thus, trout isolates reduced nitrate, assimilated citrate but not mannitol and produce the enzyme valine arylamidase but not the enzymes ester lipase $C 8$ and $\beta$-glucosidase, while the type strain of C. shigense CCUG $61059^{\mathrm{T}}$ gave opposite reactions for these traits.

Widely spread microorganisms are usually genetically heterogeneous [21]. Members of the genus Chryseobacterium are isolated from a wide range of environments [1] and therefore, it could be expected to be genetically diverse. However, trout isolates exhibited undistinguishable RAPD fingerprints indicating that they represent a single strain. This fact, together with their isolation in pure culture from internal organs might suggest a clinical significance; however the role of $C$. shigense as the causative agent of the disease episodes in trout cannot be undoubtedly established in absence of experimental infections trials.

Some members of the family Flavobacteriaceae, as Chryseobacterium, usually are opportunistic pathogens [4], because they require the existence of different predisposing factors such as coinfections with other bacteria or virus [7] or other environmental or husbandry sources of stress. No infestations or viral infections were detected previously to the disease episodes, but these usually occurred after transportation of rainbow trout fry from the hatchery to fish farm, or in tanks with elevated stock densities. These circumstances represent stressful conditions for fish [22] and might have increased the susceptibility of fry trout to infection.

Several species of Chryseobacterium, such as C. piscicola [8], C. chaponense [11], and C. shigense in this study, have been isolated from diseased fish in which F. psychrophilum infections were initially suspected. Although there are no clear evidences for considering these species as consistent pathogens for fish, they should be considered for a differential diagnosis in those cases with a suspicious of $F$. psychrophilum infection. Table 1 shows some phenotypic characteristics that can be useful for their differentiation.

Since the initial description of $C$. shigense from a fresh lactic acid beverage in Japan [20], no further isolations of this species have been reported. Consequently, the isolation of $C$. shigense from trout shows that it can also occur in a very different habitat. To our knowledge, this is the first description of the isolation of $C$. shigense from clinical specimens.

\section{Conclusions}

In this work we describe by first time the recovery of C. shigense from clinical specimens in trout, showing

\section{Table 1 Phenotypic characteristics ${ }^{\mathrm{a}}$ that can be useful to differentiate the species $C$. shigense, C. piscicola, C. chaponense and F. psychrophilum}

\begin{tabular}{|c|c|c|c|c|}
\hline Characteristic & $\begin{array}{l}\text { C. } \\
\text { shigense }\end{array}$ & $\begin{array}{l}\text { C. } \\
\text { piscicola }\end{array}$ & $\begin{array}{l}\text { C. } \\
\text { chaponense }\end{array}$ & $\begin{array}{l}\text { F. } \\
\text { psychrophilum }^{b}\end{array}$ \\
\hline \multicolumn{5}{|l|}{ Growth at/with: } \\
\hline $37 C$ & - & - & + & - \\
\hline $3.0 \% \mathrm{NaCl}$ & W & + & - & - \\
\hline $\begin{array}{l}\text { Flexirubin-type } \\
\text { pigment }\end{array}$ & + & + & - & + \\
\hline \multicolumn{5}{|l|}{ Hydrolysis of: } \\
\hline Casein & + & - & - & + \\
\hline L-tyrosine & + & - & - & V \\
\hline Gelatin & + & + & - & + \\
\hline Starch & + & + & - & - \\
\hline DNA & - & W & - & - \\
\hline \multicolumn{5}{|l|}{ Enzyme activity: } \\
\hline a-glucosidase & - & + & + & V \\
\hline$\beta$-glucosidase & - & + & + & V \\
\hline$\beta$-galactosidase & - & - & - & V \\
\hline
\end{tabular}

${ }^{a}$ Data for $C$. shigense are taken from this study, for $C$. piscicola from reference llardi et al. [8], for C. chaponense from reference Kämpfer et al. [11] and for F. psychrophilum from references Bernardet et al. [23], Cipriano and Holt [18] and Hesami et al. [24]. ${ }^{\text {b }}$ F. psychrophilum differs also from C. shigense by its inability to utilize glucose as sole carbon source, to hydrolyze aesculin and to produce a brown diffusible pigment on tyrosine agar. +, Positive reaction; - , negative reaction; $V$, variable reaction; $\mathrm{W}$, weak reaction. 
that it can also occur in a very different habitat to fresh lactic acid beverage where it was initially isolated.

\section{Acknowledgements}

This work was funded by the project CENIT 2007-2010 (ACUISOST) of the Spanish Office for Science and Technology (CDETI). The authors thank Juncal Fernández-Garayzábal for her assistance with the English reviewing of the manuscript.

\section{Author details}

${ }^{1}$ Centro de Vigilancia Sanitaria Veterinaria (VISAVET). Universidad Complutense, 28040 Madrid, Spain. ${ }^{2}$ Departamento de Sanidad Animal. Facultad de Veterinaria, Universidad Complutense, 28040 Madrid, Spain.

${ }^{3}$ Grupo Piszolla, S.L, 37800, Alba de Tormes, Salamanca, Spain.

\section{Authors' contributions}

LZ carried out the phenotypic and genetic analyses and participated in the analysis of the data and drafting of the manuscript. AIV participated in the design of the study, in phylogenetic analysis and drafting of the manuscript. MAP participated in the recovery of clinical specimens. LD participated in the design of the study. JFJG conceived the study and participated in its design, drafting and coordination. All the authors read and approved the final manuscript.

Received: 12 July 2011 Accepted: 7 June 2012

Published: 7 June 2012

\section{References}

1. Bernardet JF, Hugo C, Bruun B: In The Genera Chryseobacterium and Elizabethkingia, In The Prokaryotes, a Handbook on the biology of bacteria. Volume 7 3rd edition. Edited by Dworkin M, Falkow S, Rosenberg E, Schleifer KH, Stackebrandt E. New York: Springer-Verlag; 2006:638-676.

2. Chiu CH, Waddington M, Hsieh WS, Greenberg D, Schreckenberger PC, Carnahan AM: Atypical Chryseobacterium meningosepticum and meningitis and sepsis in newborns and the immunocompromised, Taiwan. Emerg Infect Dis 2000, 6:481-486.

3. Hsueh PR, Teng $\sqcup$, Yang PC, Ho SW, Hsieh WC, Luh KT: Increasing incidence of nosocomial Chryseobacterium indologenes infections in Taiwan. Eur50). J Clin Microbiol Infect Dis 1997, 16:568-574.

4. Bernardet JF, Vancanneyt M, Matte-Tailliez O, Grisez L, Tailliez P, Bizet C, Nowakowski M, Kerouault B, Swings J: Polyphasic study of Chryseobacterium strains isolated from diseased aquatic animals. Syst App/ Microbiol 2005, 28:640-660.

5. Mudarris M, Austin B: Systemic disease in turbot Scophthalmus maximus caused by a previously unrecognised Cytophaga-like bacterium. Dis Aquat Org 1989, 6:161-166.

6. Mudarris M, Austin B, Segers P, Vancanneyt M, Hoste B, Bernardet JF: Flavobacterium scophthalmum sp. nov., a pathogen of turbot (Scophthalmus maximus L.). Int J Syst Bacteriol 1994, 44:447-453.

7. Ilardi P, Avendaño-Herrera R: Isolation of Flavobacterium-like bacteria from diseased salmonids cultured in Chile. Bull Eur Assoc Fish Pathol 2008, 28:176-185.

8. Ilardi P, Fernández J, Avendaño-Herrera R: Chryseobacterium piscicola sp. nov., isolated from diseased salmonid fish. Int I Syst Evol Microbiol 2009, 59:3001-3005.

9. Ilardi P, Abad J, Rintamäki P, Bernardet JF, Avendaño-Herrera R: Phenotypic, serological and molecular evidence of Chryseobacterium piscicola in farmed Atlantic salmon, Salmo salar L., in Finland. J Fish Dis 2010, 33:179-181.

10. Campbell S, Harada RM, Li QX: Chryseobacterium arothri sp. nov., isolated from the kidneys of a pufferfish. Int I Syst Evol Microbiol 2008, 58:290-293.

11. Kämpfer P, Fallschissel K, Avendaño-Herrera R: Chryseobacterium chaponense sp. nov., isolated from farmed Atlantic salmon (Salmo salar). Int J Syst Evol Microbiol 2011, 61:497-501.

12. Wiklund T, Madsen L, Bruun MS, Dalsgaard I: Detection of Flavobacterium psychrophilum from fish tissue and water samples by PCR amplification. J Appl Microbiol 2000, 88:299-307.

13. Vela Al, Collins MD, Lawson PA, García N, Domínguez L, FernándezGarayzábal JF: Uruburuella suis gen. nov., sp. nov., isolated from clinical specimens of pigs. Int I Syst Evol Microbiol 2005, 55:643-647.
14. Saitou N, Nei M: The neighbour-joining method: a new method for reconstructing phylogenetic trees. Mol Biol Evol 1987, 4:406-425.

15. Marmur J: A procedure for the isolation of deoxyribonucleic acid from micro-organisms. J Mol Biol 1961, 3:208-218.

16. Bernardet JF, Nakagawa Y, Holmes B: Proposed minimal standards for describing new taxa of the family Flavobacteriaceae and emended description of the family. Int J Syst Evol Microbiol 2002, 52:1049-1070.

17. Zamora L, Fernández-Garayzábal JF, Palacio MA, Sánchez-Porro C, SvenssonStadler LA, Domínguez L, Moore ERB, Ventosa A, Vela Al: Chryseobacterium oncorhynchi sp. nov., isolated from rainbow trout (Oncorhynchus mykiss). Syst Appl Microbiol 2011, 35:24-29.

18. Cipriano RC, Holt RA: Flavobacterium psychrophilum, cause of bacterial cold-water disease and rainbow trout fry syndrome. Fish Disease Leaflet 2005, 86:1-44.

19. Woo PCY, Lau SKP, Teng JLL, Tse H, Yuen KY: Then and now: use of $16 \mathrm{~S}$ rDNA gene sequencing for bacterial identification and discovery of novel bacteria in clinical microbiology laboratories. Clin Microbiol Infect 2008, 10:908-934.

20. Shimomura K, Kaji S, Hiraishi A: Chryseobacterium shigense sp. nov., a yellow-pigmented, aerobic bacterium isolated from a lactic acid beverage. Int J Syst Evol Microbiol 2005, 55:1903-1906.

21. Martín V, Vela Al, Gilbert M, Cebolla J, Goyache J, Domínguez L, FernándezGarayzábal JF: Characterization of Aerococcus viridans isolates from swine clinical specimens. J Clin Microbiol 2007, 45:3053-3057.

22. Georgiadis MP, Gardner IA, Hedrick RP: The role of epidemiology in the prevention, diagnosis, and control of infectious diseases of fish. Prev Vet Med 2001, 48:287-302.

23. Bernardet JF, Segers $P$, Vancanneyt M, Berthe F, Kersters $K$, Vandamme P: Cutting a Gordian knot: emended classification and description of the genus Flavobacterium, emended description of the family Flavobacteriaceae, and proposal of Flavobacterium hydatis nom. nov. (Basonym, Cytophaga aquatilis Strohl and Tait 1978). Int I Syst Bacteriol 1996, 46:128-148.

24. Hesami S, Allen KJ, Metcalf D, Ostland VE, Maclnnes JI, Lumsden JS: Phenotypic and genotypic analysis of Flavobacterium psychrophilum isolates from Ontario salmonids with bacterial coldwater disease. Can $J$ Microbiol 2008, 54:619-629.

doi:10.1186/1746-6148-8-77

Cite this article as: Zamora et al:: First isolation and characterization of Chryseobacterium shigense from rainbow trout. BMC Veterinary Research $20128: 77$.

\section{Submit your next manuscript to BioMed Central and take full advantage of:}

- Convenient online submission

- Thorough peer review

- No space constraints or color figure charges

- Immediate publication on acceptance

- Inclusion in PubMed, CAS, Scopus and Google Scholar

- Research which is freely available for redistribution

Submit your manuscript at www.biomedcentral.com/submit

C Biomed Central 